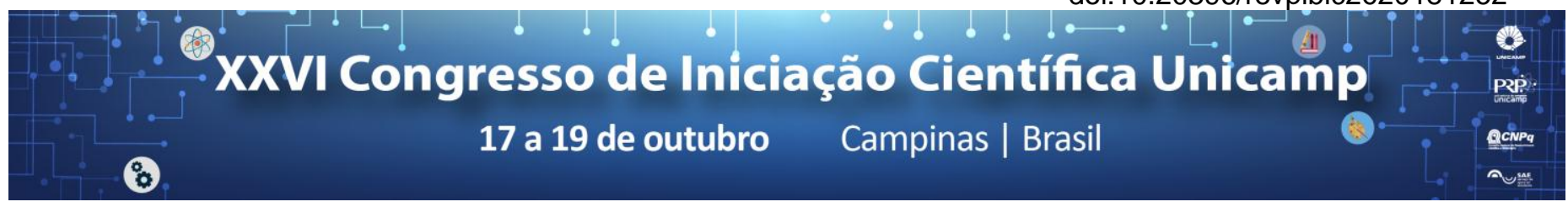

\title{
Avanços e Retrocessos da Participação Feminina nas Organizações Partidárias Brasileiras
}

\section{Simone Boró*, Andrea Marcondes de Freitas}

\begin{abstract}
Resumo
Esse projeto investiga a composição feminina nos partidos políticos brasileiros e como esta organização reflete na baixa obtenção de cargos eletivos pelas mulheres. Para tanto, analisaremos no âmbito estadual as 35 agremiações partidárias registradas no Tribunal Superior Eleitoral (TSE) a fim de verificarmos, em níveis quantitativos, a estruturação organizativa dos partidos políticos e como sua configuração implica na participação feminina nos cargos eletivos, pois apesar de representarem mais da metade da população brasileira, as mulheres possuem participação minoritária nesta esfera. Dessa maneira, para o aprofundamento da análise, buscaremos demonstrar se essa diminuta participação eleitoral feminina corresponde a uma implicação direta das configurações partidárias vigentes no país.
\end{abstract}

\section{Palavras-chave:}

Organização partidária, partidos políticos, representação feminina.

\section{Introdução}

A desigualdade na representatividade por gênero no país, marca perniciosa e generalizada, é refletida no âmbito político pela baixa representação feminina nas esferas decisórias, ou seja, o acesso à política formal para as mulheres não corresponde à sua proporção na sociedade brasileira.

Para a problematização desta questão, objetiva-se a análise da participação feminina na composição interna dos partidos políticos brasileiros a fim de observar como esta organização dos diretórios reflete a diminuta obtenção dos cargos pelas mulheres na disputa eleitoral. Visa-se, assim, constatar se há barreiras dentro da própria estrutura partidária que resultam na baixa representatividade das mulheres em cargos eletivos.

Para atingir tal objetivo, construímos uma base de dados com as informações das composições dos diretórios estaduais, compreendendo, assim, os filiados das 35 siglas político-partidárias registradas no Tribunal Superior Eleitoral (TSE) desde o início da série de registro respectiva de cada agremiação política até o ano de 2017. Através da análise desses dados pretendemos apontar se essa desproporção na representatividade feminina é uma implicação direta das configurações partidárias vigentes no país.

\section{Resultados e Discussão}

A criação de um banco de dados com as informações dos diretórios estaduais referentes às 35 composições partidárias registradas no TSE permitiu-nos verificar que a participação feminina nas organizações dos partidos políticos representa, em média, apenas $24 \%$, enquanto que o gênero masculino compõe $75 \%$ de sua estrutura. Essa desigualdade acentua-se quando verificamos a porcentagem de mulheres nos cargos mais elevados, como presidente e vice-presidente, constituindo-se a representação feminina em apenas 16\%. Diante desses resultados obtidos, pontuamos que para além da diminuta representação intra-partidária das mulheres, os cargos mais significativos na estrutura de comando político e de distribuição de recursos tendem a ser, majoritariamente, delegados ao gênero masculino, preponderando em $83 \%$ das vagas.
Figura 1. Participação Feminina nas Organizações Partidárias Brasileiras por Cargo e Porcentagem Geral

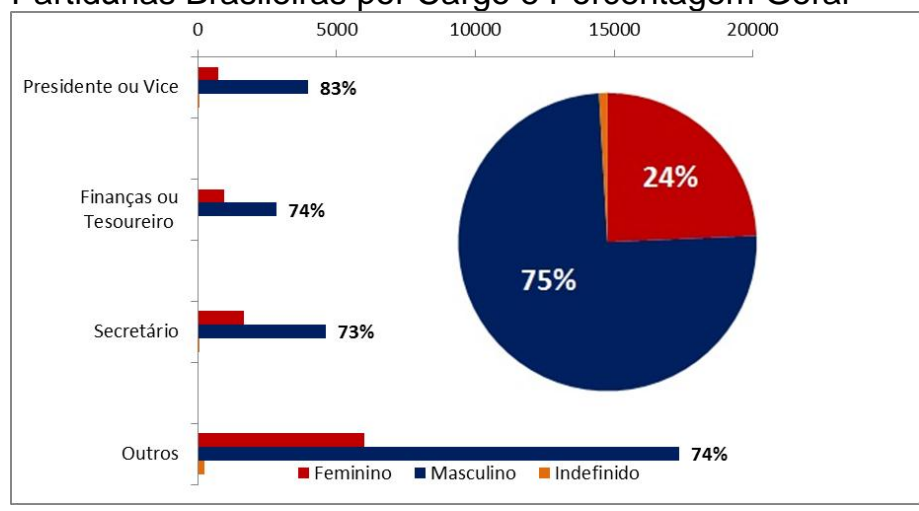

\section{Conclusões}

A baixa representatividade feminina na obtenção de cargos eleitorais pode ser tida como um reflexo direto da diminuta participação das mulheres nas organizações partidárias brasileiras, pois se os instrumentos partidários não estimulam a igualdade de gênero internamente, o resultado eleitoral não se apresentaria de modo distinto. Dada a gravidade da desproporção dos cargos ocupados por mulheres nas organizações partidárias, impor-se-ia ao legislador a adoção de medidas legais, como a possibilidade da reserva de $30 \%$ das vagas intrapartidárias, em simetria ao parâmetro adotado para as cotas de candidaturas femininas, instituída pela Lei $\mathrm{n}$ ㅇ. 9.504, de 30 de setembro de 1997. Com esse intuito, uma parcela dos cargos das organizações dos partidos, inclusive a de líderes, poderiam ser ocupadas por mulheres, ampliando a participação feminina na política.

\section{Agradecimentos}

Agradece-se a todos que contribuíram, direta e indiretamente, para a concepção desta pesquisa, em especial, ao fomento prestado pelo CNPq e a orientação da Prof ${ }^{a}$. Dra. Andréa Marcondes de Freitas.

BOLOGNESI, Bruno. A cota eleitoral de gênero: política pública ou engenharia social? Revista Paraná Eleitoral. Curitiba, vol. 1, no 2, pp. 113-129, 2012 .

GUARNIERI, Fernando Henrique Eduardo. A Força dos Partidos "Fracos". Revista de Ciências Sociais. Rio de Janeiro, vol. 54, nº 1, pp. 235-258, 2011. 